\title{
WALT WHITMAN AND ABBY PRICE
}

\author{
Sherry Ceniza
}

Picture a Brooklyn brownstone in the 1850s. Like the ones in Brooklyn Heights and the Fort Greene area today, it had five floors, counting the ground-level floor, which Louisa Van Velsor Whitman always referred to as the basement. Such a brownstone could accommodate several families, which was the case with the circle of people who surrounded Louisa Whitman. She took in boarders and housed family members in her Brooklyn home-her son Jeff and daughter-in-law Mattie and their two children, as well as her sons Eddie, sometimes Jesse, and Walt until he moved to Washington in December 1862. Another member of the Whitman circle used a nearby brownstone as an extended family home. Her name was Abby Price. She lived in what is now called the Brooklyn Heights area, west of Fort Greene Park and the present-day Walt Whitman Houses. She was one of Whitman's best friends from 1856 until she died in 1878, and the story of their remarkable friendship-and the impact that friendship had on Whitman's writing-has never been told.

Brownstones offered the space needed for a large single family or for a combined household or for boarders. Such a structure suited Abby Price since she shared her home with another family once she moved to Brooklyn from the Raritan Bay Union, a Fourierist commune near Perth Amboy, New Jersey; before that she had lived for eleven years at the Hopedale Community, a Christian socialist commune in Massachusetts. She was, then, an associationist, or one of the early socialists active in the 1840s up until the Civil War who were intent on changing the social, political, and economic structures of their society. In time, Abby moved from Brooklyn across the East River to Manhattan and became part of a workers' cooperative. In early 1878, she moved to Red Bank, New Jersey, to live and to die at the Phalanx, the building which had at one time been the communal house for the members of the North American Phalanx, a Fourierist commune which lasted from 1843 to 1854. By the time Abby moved to Red Bank with her husband Edmund, the phalanstery had become a boarding house. On May 3, 1878, Abby fell down some stairs in the night and died the next morning. ${ }^{1}$

Abby and Walt's friendship should come as no surprise. She was, after all, one of those leaders of reform he spoke of in a notebook entry: "My final aim To concentrate around me the leaders of all reforms -transcendentalist, spiritualists, free soilers."2 Until she moved to the 
Raritan Bay Union, Abby consistently served as an officer and committee member for the New England Non-Resistance Society and the Anti-Slavery Society. Because she lived at Hopedale, she had opportunities most other women of her time never even dreamed of. She voted in Hopedale elections; she held some of the highest offices possible in her community; she preached; she gave speeches at neighboring villages; she advocated that Hopedale women work the soil the same as men; she wrote repeatedly on the need for a Hopedale communal kitchen in order to give women time for self-development; she published; she served as the town bard, so to speak, writing "occasional" poems before she began writing commentary; she wore the bloomer. ${ }^{3}$ She gave speeches at the first three national women's rights conventions. She stressed over and over the need for women to have healthy, strong bodies.

Beginning in 1850, though, Price focused on one interest-Women's Rights. From 1850 to July 1853, she wrote numerous articles on women's rights and presented speeches at the first three national women's rights conventions $-1850,1851$, and $1852 .{ }^{4}$ In 1850 , her writing style changed: her writing voice became more authoritative and confident as she began to employ the personal "I" instead of the editorial "we," affirming that it was her own voice, a woman's voice, speaking. The Tribune carried her report on the 1852 women's rights convention;" the Practical Christian regularly printed her articles, speeches, and poems; the New Era and the Liberator occasionally ran her poems; and the published proceedings of the conventions contained her speeches. One of the publishers of these proceedings was the firm of Fowler and Wells, where Whitman spent a great deal of time until the latter part of the 1850s. Lydia Fowler, author and wife of Lorenzo Niles Fowler, actively participated in the early women's rights conventions. Because of the published accounts of these conventions and because of the Whitman/ Fowler connection, Whitman had ample opportunity to become familiar with Price's views as they appeared in print and, perhaps, from conversations with Lydia Fowler before he and Price met and began their own talks, the talks he refers to so frequently in his letters to her: "I wish you lived here-" he wrote Abby from Boston; "I should visit you regularly every day - probably twice a day." "Abby, I think often about you, \& the pleasant days, the visits I used to pay you $\&$ how good it was always to be made so welcome," he wrote to her from Washington. "O I wish I could come in this afternoon, \& have a good tea with you, \& have three or four hours of mutual comfort \& talk, \& be all of us together again."6

"All of us" consisted of Abby Price, her two daughters Helen and Emily, her son Arthur and husband Edmund, the family friend George B. Arnold, boarders, and a large circle of friends. But primarily Whit- 
man meant himself, the Prices, and George B. Arnold, who shared the Price home and whose friendship Whitman also valued. ${ }^{7}$ Certainly Whitman had in his friendship with Price one of the richest resources possible for understanding the issues underlying the early women's rights movement in America. She was the kind of woman he came to call "woman under the new dispensation"8 - in no way a Victorian Lady.

He saw in her and her activist friends women with hopes for a different kind of life. He met many of her friends-among them Paulina Wright Davis, Ernestine L. Rose, and Sarah Tyndale-who, along with Price and Lucretia Mott, dominated the first National Woman's Rights Convention in 1850 . Abby Price's main point in the speech she gave at this convention was that the socially prescribed boundary lines that kept women from active participation in public life had to be eradicated.

Prescribed boundary lines were precisely what Whitman worked against, politically and poetically, in the 1855 edition of Leaves of Grass. In "Song of Myself," for instance, he often places his poet-persona spatially in such a way that he looks out over expanses of land and indicates to his companions (and thus, his readers) that the open land served in essence as a metaphor for possibilities, for an unbounded life. What is distinctive about Whitman is that he includes women among these companions:

What is known I strip away,

I launch all men and women forward with me into the Unknown. . . .

But each man and each woman of you I lead upon a knoll,

My left hand hooking you round the waist,

My right hand pointing to landscapes of continents and the public road. ${ }^{9}$

Including women in this panoramic view of possibilities certainly was one way Whitman worked against the very norms that women activists were resisting. But in the 1856 edition of Leaves, Whitman sharpens his images of women who appropriate public space as their right; he also increases the number of these images. In the 1855 Leaves of Grass, the poet-persona suggests possibilities for women; in the 1856 edition, women act. For these reasons, the 1856 edition of Leaves provides a dramatic echo of the public voices of women Whitman either heard at the convention halls or read about as he picked up the New York papers. It also echoes the words he heard from Abby Price herself.

This edition, then, reflects not only the public agitation and the heightened visibility of women's issues which grew out of the conventions, but it also responds to Whitman's remarkable friendship with Abby Price. Price's speeches are filled with metaphors of the cramped space - both physical and mental - that women were forced by society to occupy. The language in the 1856 Leaves opens up these spaces. This 
edition, more than any other, seems to answer, as if in dialog, specific concerns Price addressed in her speeches. For example, the women in the 1856 Leaves aren't always-as is often assumed-mothers or sisters or mates or daughters. They move out into public space, and they assume the role of citizens, of human beings in their own right. After the 1855 Leaves, women not only appear more frequently in Whitman's poetry but in his prose as well, beginning with An American Primer, written (though not published) around the same time that Whitman met Abby Price. ${ }^{10}$ By 1856 , then, women were starting to occupy more space in Whitman's written visions of America.

The nature of Price and Whitman's friendship is striking in its reciprocity. In the letters, he never condescends; she doesn't defer. They spoke to each other as the best of friends do-in a direct manner. Walt: "Abby, mind the address-your last letter went wrong-had the wrong state $-{ }^{11}$ And Abby: "You see Harland right away and tell him about it and find out who the Committee are, and I guess if you have time enough you can get it done and I shall have the fun of sending you the check!" 12 Though Abby asked him to do favors for her when he was in Washington, he relied on her as well. For example, he stayed at the Price home twice when he came to Brooklyn on leave from his Washington job, in 1866 and 1868.

Price's circle of friends gave Whitman a sympathetic forum. Helen Price tells of the time Walt came over with "Out of the Cradle Endlessly Rocking" stuffed in his pocket, and she recalls Whitman, Arnold, and Abby Price reading it aloud. Arnold preferred Whitman's reading; Whitman, Price's. ${ }^{13}$ Helen also tells of Abby going over to see Whitman's mother and reading aloud to her "The Mystic Trumpeter." ${ }^{14}$ But the friendship that stands out in the Price/Whitman circle is Abby and Walt's. Helen Price describes it:

It was in talking with my mother on the spiritual nature of man, and on the reforms of the age and kindred themes, that [Whitman] took special delight. These appeared to be his favorite topics, and she, having similar sympathies and tastes, would take an equal pleasure with himself in discussing them. It was the society of my mother that was certainly Walt Whitman's greatest attraction to our house. ${ }^{15}$

Whitman himself offers a view of them, sitting around the kitchen table talking: "I was down late to breakfast this morning," he wrote Ellen O'Connor; "had a good breakfast though-nobody home but Mrs. Price \& Mr. Arnold ... . after breakfast we sat leisurely \& had a good chat-subject, the Roman Catholic religion-"16 Knowing what Price was saying in the 1850s provides fresh insights into Whitman's views of women in a democratic society, and it grounds his statements about women historically in such a way that we can do more than just theorize 
about such views. In this essay, I will focus on Price's main concern: the space a woman occupied (or could occupy) in her society.

She felt that in order for women to be mentally and spiritually free, they could not be restricted in their movements. They had to have access to public space. They also had to transform the way they thought about the private space of home. And in order to assure their freedom, they had to be economically independent-or at least had to have that as an option. She said they had to have equal pay for equal work and that their work had to have comparable worth with a man's. ${ }^{17}$

Price's argument for equality of access to public space was one Whitman listened to keenly; an analogous argument-how the unsettled Western land had to be free space (free soil) - had convinced him to leave the Democratic party. On a more general level, Whitman's whole poetic and political program, theoretically at least, pushed for the removal of boundary lines. And so did Price's. Her language constantly worked against the boundary lines her society had constructed for women. By the time she met Whitman, she had clearly and publicly articulated her argument against a restricted work place and unequal pay. These were concerns Whitman shared, but ultimately his main concern was for white working-class men. Theoretically, however, egalitarianism-and for Whitman that meant American democracy-allowed for no distinctions. In his 1856 letter to Emerson, he said: "Women in These States approach the day of that organic equality with men, without which, I see, men cannot have organic equality among themselves." 18

"Cramped, dwarfed, and cowed down" was one way Price phrased her conception of women's lot: "In the name of eternity, we ask our brothers no longer to proscribe our sphere. I say, then, that we are cramped, dwarfed, and cowed down, for the want of pecuniary independence." 19 She did not feel that the home rewarded women with the high sense of morality and spirituality that her society kept telling her it did. She saw such claims as bogus, as ways to flatter women in order to keep them in their "place." Over and over in her speeches, she called for women to move out of the home into the life of the public world. She wanted an open society: "employments and occupations being opened . . . woman, at every step, becomes greater in all respects; more free and dignified. . . ." She told men and women to look at what was happening around them. Women's space, they would see, "is circumscribed not by [women's] ability, but by [their] sex."20

She knew that most women were blind to the positions men-patriarchy-had allotted them, that they could sit and look out on their world, so to speak, but could not see. Women's rights needed much explanation, she said, "because woman suffers the inferiority of caste without knowing it and man as he prevents her development and growth 
thinks he is doing God's service." ${ }^{21}$ Here, she is addressing the ubiquity of sexism: precisely because it permeated society it was invisible. She was also addressing in part the problem of what critics now call gender formation, or the nature/nurture debate: the distinction between genetics and culture in forming one's subjectivity, one's notion of "individualism." Though at times Price spoke of inborn character and personality traits, she was not an essentialist. She believed women were the way they were not because they were born that way, but because men had dictated circumstances and roles which stunted their development. A "false public sentiment," a "scornful public sentiment," she called it. ${ }^{22}$ And part of this false public sentiment was women's own lack of consciousness about their "place," their own failure to see that their servile position was a result of their exclusion from the body politic, both politically and economically, and not a result of biology.

Price's method of undoing that false public sentiment involved writing articles, delivering speeches, serving as a member of committees and as an officer in reformist organizations and in her community. Whitman's method of forming a world different from that in which he lived involved writing poetry and "artful" prose. "Some day we may have a world in which the ways and means of life will be quite different from now," he told Horace Traubel late in life. ${ }^{23}$ In 1871, in Democratic Vistas, he wrote at length about the role literature would play in bringing democracy (the ideal democracy) to fruition; he called this role "the image-making faculty." 24 An "image-making faculty" was exactly what Price was calling for when she said that the "false public sentiment" would have to be changed.

In her 1851 convention speech, Price gave a graphic picture of what she considered typical of the American woman and her "allotted" space; it was the free-soil debate re-cast as a gender issue. The home becomes an "inferior circle of industry." The images she uses speak of reduction, of a woman being whittled down until she becomes nothing more than a "femme covert":

Woman is expected to be frail, delicate and dependent in order to be loved. She must be thus lovely to expect marriage, and she must be married to have a home and a subsistence. Hence she is limited to an inferior circle of industry, in which she can act only in helpless dependence upon Man's wiser guidance, and preserve her feminine character, the beauty of which consists in graceful weakness, timidity, and submission to the conventionalisms of life. In this condition she must patiently continue until some favorable circumstance affords her an opportunity of yielding up her personal identity and becoming a "Femme Covert" for the sake of a sure living! Thus marriage for a home becomes frequent, necessarily so, from the proscriptions under which Woman suffers. Should she attempt to make herself independent and self-supporting, she would be pronounced 'out of her sphere,' 'masculine' and unlovely. . . .,25 
Price kept repeating the need for women to be "pecuniarily independent. ${ }^{26}$ Women had to get out of the house. They had to work, or at least move in the world of the human (not just the biological) family. "Doom the wife and mother to the cares of home life, sacred and beautiful as it is," Price said, "and her nature is never satisfied, because it is never fully aroused and applied." Her reiterated theme was that "the pursuit of happiness" meant women engaged themselves in public life; they spurned the roles of women as nurturers only and as decorations to patriarchy: "What matters it now, to her," Abby said, "whether she treads a listing or a Brussels carpet? A nobler destiny is hers, than to be the doll of a parlor."27

Years later, in Democratic Vistas, Whitman's words echo Price's:

Democracy, in silence, biding its time, ponders its own ideals, not of literature and art only-not of men only, but of women. The idea of the women of America, (extricated from this daze, this fossil and unhealthy air which hangs about the word lady), develop'd, raised to become the robust equals, workers, and, it may be, even practical and political deciders with the men-greater than man, we may admit, through their divine maternity, always their towering, emblematical attribute-but great, at any rate, as man, in all departments; or, rather, capable of being so, soon as they realize it, and can bring themselves to give up toys and fictions, and launch forth, as men do, amid real, independent, stormy life. ${ }^{28}$

The "launching forth" involved, of course, not only women's willingness to move out of the home, it also meant that men would have to share power. It meant, Price and Whitman knew, the need for an image of women far different from the one institutionalized by the 1850s and still entrenched when Whitman wrote Democratic Vistas.

In a move rare for her times, Price turned the glorification-of-home argument in on itself. If, as her culture kept declaring, home was so important and rendered such an important service to society, why didn't men take over domestic duties or at least share the noble occupation?

If then the domestic duties are so important, to be attended to with the undivided thought that is claimed of woman, why should not the man, who has them resting upon him equally with his wife, be relieved from public affairs by those well qualified-mature and unengaged women: and so the young father have leisure to train his family, whose sons, learning soon of society['s] contempt for the opinions of disfranchised woman, need other authority than that considered by society on a par with the idiot, the insane and the criminal. ${ }^{29}$

As Price talked to Whitman, he grasped the images of restriction, of servitude. Her speech at the first National Woman's Rights Convention (October 1850) is filled with language trying to push away barriers, wanting to extend the human potential, desiring to open women's lives to a "larger family of man": 
Say not to [women] you have done all you may do, keep your minds and attention within that narrow circle, though your nature and ripened intellects would fain be interested in whatever concerns the larger family of man, and your affections, strong in a healthful growth, yearn towards the suffering and the afflicted of every country.

She kept using the word "narrow": "By thus narrowing their sphere, and curtailing their rights and resources, women are doomed to an endless routine of domestic drudgery, to an indoor sedentary life, with little or no stimulus to great or noble endeavors." 30 She wanted space, free-soil, "a larger circle of wants":

[Woman] needs to have her whole nature developed and strengthened by exercise; her attention directed to a larger circle of wants than those of her own household. She needs fully to apprehend the condition of the world; in fact, to realize the actual of the life she wishes her children to fill. This she cannot do, without some experience in its struggles and its triumphs. ${ }^{31}$

In his 1856 "Poem of the Road," Whitman called to women to do just what Price proposed, "to realize the actual of life":

Whoever you are, come forth! or man or woman come forth!

You must not stay sleeping and dallying there in the house, though you built it, or though it has been built for you.

Out of the dark confinement! out from behind the screen!

It is useless to protest, I know all and expose it. . . .

Home to the houses of men and women, among their families, at the table, in the bed-room, everywhere,

Smartly attired, countenance smiling, form upright, death under the breast-bones, hell under the skull-bones,

Under the broad-cloth and gloves, under the ribbons and artificial flowers,

Keeping fair with the customs, speaking not a syllable of itself,

Speaking of any thing else, but never of itself. ${ }^{32}$

It is as if Whitman is calling to the very women Price has described. It is as if that twenty-ninth bather the poet-persona speaks of in the 1855 Leaves (in the poem that would come to be titled "Song of Myself") now actually has an option. She does not have to stay there in her fine home, looking out the window, seeing the twenty-eight young men, "all so friendly ... dancing and laughing along the beach." 33 She now is invited to "come forth!" She is included in this journey down the open road, the public road. The land is hers; it's truly free soil! The constricting conception of "home" that was so eulogized in her own time in the speeches, magazines, churches, schools, gift-books, self-improvement books - this "home" is being spurned by the poet. This poet says that he inhales "great draughts of space / The east and the west are mine, and the north and the south are mine." 34 His is no narrow sphere: ". . . man or woman come forth! / You must not stay sleeping and 
dallying there in the house, though you built it, or though it has been built for you. / Out of the dark confinement!"35 Out of the dark confinement of the boundaries of home, but also out of the dark confinement of sexual boundaries. He calls to women to conceptualize for themselves the same possibilities of space as he has imagined for himself.

Abby Price found such calls exciting, crucial, liberating, offering a means for resistance. To conceptualize possibilities (open space, free soil) was the first step in understanding that the narrowness of women's lives was a result of "false public sentiment." Price, like Whitman, felt that lasting change came slowly, through evolution, not revolution, and so she knew the significance of image-making work, the product of Whitman's "image-making faculty." 36 In the "Broad-Axe Poem," for example, women "walk in public processions in the streets the same as the men / . . . they enter the public assembly and take places the same as the men." 37 These 1856 images of women reveal women "under the new dispensation"; they portray women like Abby Price. But in one instance Whitman goes beyond even Price. In An American Primer, he virtually explodes gender-demarcated space. There he addresses a notion of citizenship still very strong in the 1850 s - that in order to qualify for citizenship, one had to be able and willing to bear arms in defense of country: "In American city excursions, for military practice, for firing at the target, for all the exercises of health and manhood-why should not women accompany [men]?" When Whitman speaks of "American city excursions" and goes on to say, "I expect to see the time in Politics, Business, Public Gatherings, Processions, Excitements, when women shall not be divided from men, but shall take their part on the same terms as men," he makes a truly radical statement. ${ }^{38}$ Abby Price knew the physical improbability of such extreme public involvement for women. Though An American Primer was not published during Whitman's lifetime, in that work-inspired by his frequent discussions with Price-he imagined into existence a radical conception of women's space. ${ }^{39}$

Price knew that "false public sentiment" kept women from joining the public parade Whitman referred to, but she didn't stop with such an abstraction. She knew there were very tangible material realities at work creating the boundaries that kept women out of public office and public space, and, for the most part, out of work: that kept them dependents. The strongest material force working against women was patriarchy's success in getting women to deny their bodies. ${ }^{40}$ This denial was accomplished through various forces-one was the physical debilitation women experienced through excessive child bearing (doing their eugenic civic duty by providing baby Americans to fill up those empty Western spaces); ${ }^{41}$ another was the kind of medical care available to 
women during pregnancy and childbirth (having a woman's body often insured a premature death); and another was women's dress. Price knew the power the body politic exerted by controlling the personal body. She understood the politics of dress, the mixing of the personal and the public. She made it clear that she connected a woman's dress with her health, sexuality, and work. ${ }^{42}$

The kind of clothing women (or men) wore determined quite primary things - like how fast a person could walk and whether a person could run. If a woman were threatened physically, could she run to get away? Could she, Price asked, work in the garden, on the farm, ride horseback, sail a boat, walk up and down stairs with her hands free, without having to hold up her skirts; could she operate heavy machinery not having to worry about her skirts getting caught and causing injury or death? And what about the body itself? Corseted and weighed down by the heavy material of their antebellum costumes, women's very bodies were overtaxed and weakened and distorted. ${ }^{43}$ At the second National Woman's Rights Convention, Price made an indisputable connection between dress and dependence:

Woman is at present to a great extent unfitted by her dress for self-support and independence; she is almost necessarily restricted to sedentary pursuits by this attire, and although not the cause of this restriction, yet it is a style that she long ago would have discarded, had she had equal rights to employment according to choice, and as many and as noble objects placed before her for personal achievement."44

Price no doubt had mixed feelings when she saw the frontispiece of the 1855 Leaves of Grass, with Whitman dressed in the loose-fitting, simple clothes that were the opposite of the fashion for middle-class men, and were unthinkable for middle-class women. Whitman's clothes, which Bronson Alcott called his "man-Bloomer" ("he wears his man-Bloomer in defiance of everybody"), ${ }^{45}$ were even less cumbersome and ornamented that the woman-Bloomer Price had worn in 1851-1852. She had led the way in her part of Massachusetts by inciting women to adopt this new kind of clothing. After a year of public vilification, however, she finally gave up wearing the bloomer in public because she felt that instead of bringing benefits, it actually harmed her cause. Because she gave it up, she was publicly criticized. She replied to one of her critics:

I honor the dress and still enjoy its convenience and neatness wherever I deem it wise to wear it; and only regret that I have not done more to advance its interests. As I feel at present I cannot, without being false to my highest convictions of what is wisest and best for me to do, wear the dress away from home alone. While I still award the new style the superiority, on all points that I ever did, I must be allowed to act freely, as my own conscience and experience dictate. Had I been more heroically 
organized, I might have held out better. But let me not be utterly condemned for admitting that I have not the courage $I$ thought I had. ${ }^{46}$

When she looked at the frontispiece of the 1855 Leaves, then, and saw what she knew to be the "image-making faculty" at work, she must have felt admiration for Whitman for what he was doing, yet bitterness too-that controversial though Whitman's acts and words were, as a male he was given a wider range of possibilities for resistance than she. All she had to do was to look at Frances Wright's life to see the price women in America paid for stepping out of their space. All she had to do was think of Wright's last years, isolated and impoverished, separated from her income, her daughter, and her work because she had defied Victorian conventions. Price said in another article that she would continue to wear the bloomer in the privacy of her own home. (Perhaps they sat together at the kitchen table talking, Price in her womanbloomer and Whitman in his man-bloomer.)

Price talked about the unhealthy veiling of women's bodies: the "shroud-like drapery around ... [their] feet and limbs."47 Whitman, more daringly, talked about the female body unveiled. In the 1856 Leaves, Whitman strategically placed "Poem of Women" ("Unfólded Out of the Folds") immediately after "Poem of Walt Whitman, an American" ("Song of Myself"). In some ways, "Poem of Women" is very much in keeping with its times. Its eugenic cast was quite in line with the mainstream ideology: strong mothers make strong sons (citizens). Whitman certainly played on this Republican Motherhood theme, either out of his own belief in this particular role for women or as a subversive act. ${ }^{48}$ (Many present-day feminist historians believe nineteenth-century women themselves used this role subversively.) Outside of the eugenics/Republican-Motherhood theme, however, Whitman's "Poem of Women" is a startling poem in the context of its times. Not only is it structured around vulval imagery, the poem also portrays a "strong and arrogant woman," a "well-muscled woman," and it gives credence to a woman's brain; there is even the concept of a woman's "justice" (for once, justice, rather than mercy). ${ }^{49}$

Whitman's "Poem of Procreation" ("A Woman Waits for Me") also appears in the 1856 Leaves and is probably the poem most problematic, even offensive, for contemporary women readers. It fails miserably as a re-creation of satisfying heterosexual lovemaking. Elizabeth Cady Stanton remarked on it in her diary: "I have been reading Leaves of Grass. Walt Whitman seems to understand everything in nature but woman. In 'There is a Woman Waiting for Me,' he speaks as if the female must be forced to the creative act, apparently ignorant of the great natural fact that a healthy woman has as much passion as a man, that she needs nothing stronger than the law of attraction to draw her to the male," $"$ Whitman's poem, however, does counter the notion, ob- 
sessively popularized at the time, of passionlessness in women. It speaks forthrightly about the sexuality of the body, about the sexuality of a woman's body. It also, like "Poem of Women," speaks of women's strength and their active appropriation of space through their movement:

They are tanned in the face by shining suns and blowing winds,

Their flesh has the old divine suppleness and strength,

They know how to swim, row, ride, wrestle, shoot, run, strike, retreat, advance, resist, defend themselves,

They are ultimate in their own right-they are calm, clear, well-possessed of themselves.. ${ }^{51}$

These women act. They appropriate space. They make it theirs. They claim free soil.

Again, unless put into the context of the times, the significance of this emphasis on physical strength slips by the contemporary reader. Abby Price told women that in order to secure their rights, they may, as she wryly put it, "be called on to omit homage to some household god for the acquirement of health and strength by out-door exercise." 52 In the May 19, 1860, Saturday Press, in a column right next to a long and boldly typed announcement of the 1860 Leaves of Grass, another woman spoke of the importance of physical strength to women. Ada Clare, the author, was not a suffragette; she acted in the theater, lived an unconventional personal life, and wrote. She was part of the literary group which met at Pfaff's cafe and was one of Whitman's friends. She wrote irreverently about society and about the women's movement. She worked for women's rights in her own way:

When about fourteen years of age, I was what is called in extreme scorn by school misses a hearty girl; a great deal of exercise in the open air, a devotion to running, swimming, climbing, wrestling, etc., rather than to sewing, reading, and worstedwork, had produced in me a physical development, a vigorous health, an exuberant flow of spirits, which is, alas! most rarely found in girls. I ignored sentiment, nerves, and sickness, and the time when most girls are just budding into coquetry, I spent in climbing fig-trees, turning somersaults in the grass, riding unsaddled horses, swimming in the open stream, rowing hideous little boats. . . . Women have come to think that ill-health is their birth-right, and so long as they hold that faith they will neither seriously wish for, nor obtain their true rights from those who hold them in bondage. The invalid, perennially child-bearing woman has no strength to struggle against any wrong: it is as much as she can do to keep her sick soul within her worn body. When woman begins to feel that she has a right to physical strength, sound health, good spirits, and to the bearing of no more children than her own constitution and the well-being of her offspring will allow, her rights will follow fast. ${ }^{53}$

Also in the 1856 Leaves is "Poem of Remembrances for a Girl or a Boy of These States," which Whitman eventually eliminated from Leaves of Grass. The poem can be read as Whitman's attack on society 
for its gross hypocrisy towards women. The poet addresses the "just maturing youth," charging her or him: "Remember the organic compact of These States, / Remember the pledge of the Old Thirteen thence-forward to the rights, life, liberty, equality of man. . .." By 1856 , newspapers had been filled with statements by reform-minded women charging the United States with hypocrisy, with arrogantly spurning the Declaration of Independence, the terms upon which the country had been founded. Surely, Whitman is using the imperative mode here purposefully, not just for rhetorical effect, and he is charging men and women to remember:

Remember what was promulged by the founders, ratified by The States, . . .

Remember the purposes of the founders! . . .

Anticipate the best women!

I say an unnumbered new race of hardy and well-defined women are to spread through all These States,

I say a girl fit for These States must be free, capable, dauntless, just the same as a boy.

One thing this poem is about is resistance-about the need for women to resist the illegality of their exclusion from public life and for men to face up to the illegality of this treatment. Whitman ends the poem much like he ends "Poem of Women":

Think of womanhood, and you to be a woman!

The creation is womanhood,

Have I not said that womanhood involves all?

Have I not told how the universe has nothing better than the best womanhood? 54

Thirty years later, in 1888 , Whitman said to Traubel:

Leaves of Grass is essentially a woman's book: the women do not know it, but every now and then a woman shows that she knows it: it speaks out the necessities, its cry is the cry of the right and wrong of the woman sex-of the woman first of all, of the facts of creation first of all-of the feminine: speaks out loud: warns, encourages, persuades, points the way. ${ }^{55}$

But, as Whitman said, some women knew it. Linda Gordon says that in spite of Elizabeth Cady Stanton's objection to "A Woman Waits for Me," Stanton "loved Whitman." It was largely his openness about sex, Gordon says, that also made him the free lovers' favorite poet. ${ }^{56} \mathrm{He}$ anticipated contemporary feminists' cry that the political is inextricably fused with the personal. Women like Ada Clare heard the cry of Leaves of Grass. And so did Abby Price. 
In 1872, Walt reacted angrily toward Helen Price when she, as a joke, left the Whitman home wearing one of his rings. Abby spoke of this to Louisa: "I feel very sorry such a thing has happened. It has hurt Helen very much indeed, but I hope they both will learn a good Lesson from it-Helen not to touch other peoples rings - and Walter will learn to throw his broad mantle of charity over small things as well as larger ones. However it has all passed by-and let us forgive as we are hoping to be forgiven." 57

And they did forgive. Abby offered space in her home to Walt's mother after Louisa had moved to Camden to live (unhappily) in her son George and daughter-in-law Lou's home. "i got a letter from Helen," Louisa wrote Walt; "she and her ma wants me to come to their house and stay a while but i shall never go of course but its very kind of them"58 Abby invited Walt to come stay at the Price/Arnold home after he had suffered his paralytic stroke and Louisa had died: "I want to come \& see you -" Walt answered; "must do so before long-" 59 In the last extant letter between Abby and Walt, written in October 1876, Walt wrote: "got your letter-write again-believe me, Helen and Abby dear, I appreciate the letters, \& most of all your persistent $\&$ faithful friendship." $" 60$

\section{University of Iowa}

\section{NOTES}

\section{Monmouth Democrat, May 16, 1878.}

2 Walt Whitman, Notebooks and Unpublished Prose Manuscripts, ed. Edward Grier (New York: New York University Press, 1984), 1:147. Hereafter abbreviated NUPM.

3 Freeing women from the endless routine of domestic duties was a primary concern for Price. Without relief from the constant routine, women had no choice for a world outside the home. She wanted communal sharing of household labor. In this regard, Whitman's notebook entry, dated by the Library of Congress "Before 1860," is interesting: "A simpler system of the table . . . No house, no woman, can be disenthralled until the society arrives at a simpler system of the table . . . As to who shall do the work it is just as becoming, when both understand it as, that the man cook for the woman as that the woman cook for the man" (NUPM, 1:369).

4 The first National Woman's Rights Convention was held at Worcester, Massachusetts, October 23 and 24, 1850; the second, also held at Worcester, met on October 15 and 16, 1851; the third, at Syracuse, New York, September 8, 9, and 10, 1852.

5 "Letters of Walt Whitman to His Mother and an Old Friend," Putnam's Magazine 5 (November 1908), 163.

6 Walt Whitman, The Correspondence, ed. Edwin Haviland Miller (New York: New York University Press, 1961-1977), 1:50; 1:162. Hereafter abbreviated Corr.

7 Arnold had been a Unitarian minister working among the poor in New York City in his early days; he then moved West to Pennsylvania and Illinois and was at one time a 
horticulturist, treasurer of the Illinois Mutual Fire Insurance Company, and president of the North American Phalanx and the Raritan Bay Union. He was an inventor and secured patents on attachments to the sewing machine. Various pieces of evidence suggest that Abby Price and he had a business together, which Louisa Whitman called the Magic Ruffle Business and Abby Price called Our Ruffle Manufacture, and that this business grew from a ruffle attachment Arnold invented (Letter to Whitman, Trent Collection, William R. Perkins Library, Duke University, July 14, 1870; Letter to Whitman, Beinecke Library, Yale University, March 1867). From the way Price and Louisa Whitman talk about the business, it appears to have been a workers' cooperative. Edwin Grier's note (NUPM, 2:832n) also reinforces the idea of the Price/Arnold cooperative when Grier states that Arnold is listed in the 1866-67 New York directory as "pres." This entry, Grier says, is connected with an entry for Price. Arnold was also a Swedenborgian and became, his obituary says, a believer in spiritualism. He was a scientist and spent much time in his later years on the rooftop of the Price/Arnold home with his telescope looking at the stars. (Helen Price's letters to Louisa speak of this.)

He married Lydia Spring, the sister of Marcus Spring, a New York businessman, philanthropist, and major stockholder in the Raritan Bay Union. They had three children - John, Abby, and George G. Arnold. George G. Arnold studied to be an artist, but eventually became a writer. He was a good friend of Henry Clapp's, editor of the Saturday Press, and spent time with Whitman at Pfaff's cafe, the literary hangout for Clapp, Whitman, and other writers in the 1850s. Pfaff's circle and Price's circle thus intersect.

Abby Spring Arnold married Benjamin Urner, a printer. It was Urner and Arnold that Sarah Tyndale suggested as possible publishers of the second Leaves. In the summer of 1854 Lydia Spring Arnold died and George B. Arnold left the Raritan Bay Union. He bought some of the North American Phalanx farmland near Red Bank, New Jersey, and called his land Strawberry Farms. His son George G. Arnold was buried at Red Bank; Henry Clapp spent time recuperating from bad health at Red Bank; and Abby Price died at Red Bank.

Jack Holzhueter, at the State Historical Society of Wisconsin, very generously shared with me the research he had done on Arnold when he was a research assistant for Walter Donald Kring's Liberals among the Orthodox (1974).

Edwin H. Miller, in The Correspondence, and Gay Wilson Allen, in The Solitary Singer, among others, err in identifying George B. Arnold. They call him John, who was, as I said above, one of George B. and Lydia Arnold's sons. Edwin Grier gets the identity right in NUPM, 2:832n, though he is tentative about it.

8 Walt Whitman, Manuscripts, Autograph Letters, First Editions, and Portraits of Walt Whitman Formerly the Property of the Late Dr. Richard Maurice Bucke, ed. E. F. Hannaburgh and Jacob Schwartz (New York, 1936), 82.

9 Walt Whitman, Leaves of Grass: A Textual Variorum of the Printed Poems, ed. Sculley Bradley, Harold W. Blodgett, Arthur Golden, William White (New York: New York University Press, 1980), 1:71; 1:75. Hereafter abbreviated LG Var.

10 Helen Price, Abby's daughter, said that her mother met Whitman through a mutual friend. The friend could have been Henry Clapp. Abby Price had known Clapp since the 1840s, when both of them had been active in the same societies - the Non-Resistance and the Anti-Slavery societies. Both had pieces published in an anti-slavery tract, Liberty Chimes. In the March 5, 1859, issue of the Saturday Press, Clapp printed one of Price's poems. In December 1859, Clapp printed the first of several of Whitman's poems.

Or perhaps they met through Sarah Tyndale. Tyndale, a member of the early national women's rights conventions and one of the original stockholders of the Raritan Bay Union, had worked with Price since 1850. Regardless, Walt became a frequent visitor at the Price home, and soon the three Price women befriended his mother, who, after he 
moved to Washington, frequently mentioned their visits to her in letters to Walt. Louisa and Helen became especially close. Helen told Louisa she was her "other mother" (Trent Collection, November 24, 1872). The letters they wrote to each other offer a vivid picture of life in the Price home and of the unhappy months Louisa spent in Camden.

11 Corr., 2:282.

12 Abby Price, Letter to Walt Whitman [March 25, 1867], The Beinecke Rare Book and Manuscript Library, Yale University Library, New Haven, Connecticut. This is the only letter from Price to Whitman I have been able to locate. Whitman refers repeatedly to having received letters from Price, but apparently hers were among the many letters and manuscripts he mentions destroying in 1874.

Price is referring to Thomas Harland, Chief Clerk in the Patent Office. She is concerned because she believes that her company-Our Ruffle Manufacture-is being unjustly taxed.

13 Helen E. Price, "Letter from Helen Price," in Richard Maurice Bucke, Walt Whitman (Philadelphia: David McKay, 1883), 29.

14 Helen E. Price, "Reminiscences of Walt Whitman," The Evening Post (New York), May 31, 1919.

15 Helen Price, in Bucke's Whitman, 30.

16 Corr., 2:49.

17 Abby Price was greatly indebted to Sarah Grimke, who articulated these points in her Letters on the Equality of the Sexes, 1838. She often used passages from Grimke verbatim.

Christine Stansell's City of Women (Urbana: University of Illinois Press, 1987) gives a remarkably detailed portrait of working-class women in New York City. Working-class women did not experience the demarcation of space between the public and the private spheres that middle-class white women did. However, working-class women still did not have the kind of access Abby wanted: far from it. Abby wanted equal access, equal pay for equal work, and equal pay for work of comparable worth; working-class women had none of these.

18 Walt Whitman, Leaves of Grass, Comprehensive Reader's Edition, ed. Harold W. Blodgett and Sculley Bradley (New York: New York University Press, 1965), 737.

19 Abby Price, "Address," Practical Christian, March 1, 1851.

20 Abby Price, "Address," Practical Christian, February 15, 1851.

21 Abby Price, "Does the Woman's Rights Cause Need a Paper," Practical Christian, February 12, 1853.

22 Abby Price, The Una, 1 (February 1853), 11; Abby Price, "[Report on the Behalf of the] Committee on Industrial Avocations," Proceedings of the [Second National] Woman's Rights Convention, Held at Worcester, October 15th and 16th, 1851 (New York: Fowlers and Wells, 1852), 21-22.

23 Horace Traubel, With Walt Whitman in Camden (Philadelphia: University of Pennsylvania Press, 1953), 4:177.

24 Walt Whitman, Prose Works 1892, ed. Floyd Stovall (New York: New York University Press, 1964), 2:419. Hereafter abbreviated $P W$. 
26 Early in Price's speech at the 1850 Convention she lists three changes needed in order for women to "enjoy" the right to happiness: "women ought to have equal opportunities with men for suitable and well compensated employment"; "women ought to have equal opportunities, privileges, and securities with men for rendering themselves pecuniarily independent"; "women ought to have equal legal and political rights, franchises and advantages with men." (Practical Christian, February 15, 1851). The term "pecuniary independence" runs like a motif throughout her work.

27 Abby Price, "Reasons Why Woman Should Define Her Own Sphere," The Una, 1 (February 1853), 10.

$28 P W, 2: 389$.

29 Una 1853, 10-11.

30 Practical Christian, March 1, 1851.

31 Una 1853, 10.

32 LG Var., 1:236-237.

33 LG Var., 1:12.

34 LG Var., 1:229.

35 LG Var., 1:236.

36 Later, Whitman's despair over the Kansas-Nebraska Bill, the Dred Scott decision, the Fugitive Slave Act-politics in general in the 1850-led him to believe war was the way to keep the union intact and altered his evolution-rather-than-revolution stance.

37 LG Var., 1:182.

38 Walt Whitman, An American Primer (Stevens Point, Wisconsin: Holy Cow! Press, 1987), 13.

39 Donald E. Pease's chapter "Walt Whitman and the Vox Populi," in Visionary Compacts (Madison: University of Wisconsin Press, 1987), puts Whitman's passages about women and public gatherings into an interesting perspective. Pease talks about the relationship between the crowd (the democratic masses) and the individual's "body electric." In an eloquent but somewhat oblique argument, Pease underscores the importance of public or national holidays to Whitman. Pease says that in Whitman's view, they "produced an internal life, a cultural unconscious for the masses more enduring than the opinions politicians mobilized into majority votes. These national spectacles, ritually reenacted, constituted for urban crowds that 'central spirit,' that 'image-making work' that Whitman's poetry aspired to be" (113). Sean Wilentz, in Chants Democratic (New York: Oxford, 1984), also speaks of the public spectacles, especially the artisan guild parades. Women seldom played planned leadership roles in these ritualized spectacles. In the sense that Pease means it, women were shut out of the "cultural unconscious." If Pease is right about the importance of public events to Whitman, and I agree with him, women had to assume active roles in the long parade in order for Whitman's kind of democracy to come into being.

40 Judith Fetterley, in her introduction to Provisions: A Reader from 19th-Century American Women (Bloomington: Indiana University Press, 1985), makes an invaluable observation about women's bodies and nineteenth-century American women's fiction. She says that nineteenth-century American women writers did not "extrapolate from 
their lives, their experience, and their perspective, and . . . see themselves as representative, universal, symbolic." An American woman, she says, might have gone whaling, but she wouldn't have seen herself in the whale, or as the whale. "Such attitude toward and subsequent use of the self was not, I would argue, available to women writing in America in the nineteenth century as it was to men, and as a result a certain imaginative quality that we currently identify with great American texts does not appear in their work." She mentions Dickinson and Stowe as exceptions. She goes on to say that the difficulty facing nineteenth-century American women writers lay in part with the body:

Moby Dick, after all, makes an explicitly sexual reference, and the ease with which Melville moves from self to whale depends literally on his ability to contemplate his body as a subject and project it into his text. It would have been difficult indeed for nineteenth-century American women writers to have achieved a similar comfort with the idea of their flesh (29).

Fetterley mentions a short story by Harriet Prescott Spofford ("Circumstance") as an exception. Interestingly, William D. O'Connor related to Whitman that Harriet Prescott Spofford (1835-1921) "always and everywhere" said that Whitman was "the only poet that ever lived who has done justice to woman" (Traubel 3:564).

Fetterley is making an acute observation here. Calling attention to the physicality of women's bodies is precisely what the "Children of Adam" poems accomplished at the time of their publication. Though these poems may be objectionable to many twentieth-century women readers, if read in historical context the "Children of Adam" poems become significant politically. Women's physicality is what Price (and other feminists of the times) wanted to image into being but, given widespread prejudice, found almost impossible to accomplish.

41 Linda Gordon in Woman's Body, Woman's Right (New York: Penguin, 1977) discusses eugenics and its role in women's rights. Harold Aspiz's chapter, "The Stale Cadaver Blocks Up the Passage," in Walt Whitman and the Body Beautiful (Urbana: University of Illinois Press, 1980), focuses on Whitman and the significance of the eugenics program to him.

42 Whitman was well aware of the connection. Thirty years after Price wrote about the connection between the physical body and the public body and women's servitude, Whitman, no doubt recalling his talks with Price, wrote in "Memorandum at a Venture":

To the movement for the eligibility and entrance of women amid new spheres of business, politics, and the suffrage, the current prurient, conventional treatment of sex is the main formidable obstacle. The rising tide of 'woman's rights,' swelling and every year advancing farther and farther, recoils from it with dismay. There will in my opinion be no general progress in such eligibility till a sensible, philosophic, democratic method is substituted ( $P W, 2: 494)$.

Whitman is talking about birth control as well as sexuality here.

43 An unsigned article on women's health, "A Chapter on Females," appeared in the March 26, 1849, issue of the Practical Christian. In the editorial column of the December 17, 1858, issue of the Brooklyn Daily Times an article entitled "Health Among Females" appears. (Emory Holloway and Vernolian Schwarz in I Sit and Look Out: Editorials from the Brooklyn Daily Times date "Health Among Females" as October 17. I 
found, however, in working with the microfilm of the paper that the correct date is December 17. There was no October 17 issue.) The 1858 Times article is an almost verbatim reprint of the one that appeared in the 1849 Practical Christian! Perhaps Abby told Walt about the 1849 article and he borrowed it from her file of Practical Christian issues and reprinted it, in 1858, with slight alterations. However, it is possible that the article was originally Whitman's, from the Brooklyn Freeman, which he was editing in 1848-1849.

44 Proceedings 1851, 25.

45 Gay Wilson Allen, The Solitary Singer (Chicago: University of Chicago Press, 1985), 202.

46 Abby Price, “The Bloomer Costume-Again," Practical Christian, October 9, 1852. In a letter to Susan B. Anthony, February 19, 1854, Elizabeth Cady Stanton echoed Price's argument, advising Anthony to stop wearing the bloomer: "We put the dress on for greater freedom, but what is physical freedom compared with mental bondage? . . . It is not wise, Susan, to use up so much energy and feeling that way. You can put them to better use. I speak from experience." (Eleanor Flexner, Century of Struggle [rev. ed., Cambridge, Mass.: Belknap Press of Harvard University Press, 1975], 84.)

47 Proceedings 1851, 25.

48 In "The Federal Mother: Whitman as Revolutionary Son" (Prospects 10 [1985], 423-441), Betsy Erkkila suggests that the American Revolution and its use of female iconography were germinal influences on Whitman. She extends this discussion in her recently published Whitman the Political Poet (New York: Oxford University Press, 1989). In the conclusion to her book, she speaks of the ending of Democratic Vistas, of Whitman's image of America as the divine Mother: "the future that Whitman imagined-and the only future possible for America-was in the image of a divinely charged matriarch, self-poised, swinging through time" (316-317).

49 LG Var., 1:160-161

50 Elizabeth Cady Stanton, [Excerpt from Diary] in The Feminist Papers, ed. Alice S. Rossi (New York: Columbia University Press, 1973), 393.

51 LG Var., 1:239

52 Proceedings 1851, 26.

53 Ada Clare, "Thoughts and Things," Saturday Press, May 19, 1860.

54 LG Var., 1:252-253.

55 Traubel (New York: Rowman and Littlefield, 1961), 2:331.

56 Gordon, 99.

57 Trent, probable date October 13, 1872.

58 Trent, April 12, 1872.

59 Corr., 2:267.

60 Corr., 3:62. 